\title{
Coal bottom ash characterization aiming the incorporation in cellular concrete
}

\author{
Caracterização da cinza pesada de carvão vi- \\ sando a aplicação em concreto celular
}

\author{
Fernanda Pacheco ${ }^{1}$, Michael Anderson Bica Moreira ${ }^{1}$ \\ Marlova Piva Kuwakowiski ${ }^{2}$, Feliciane Andrade Breh ${ }^{2}$, Bernardo Fonseca Tutikian ${ }^{3}$
}

\begin{abstract}
${ }^{1}$ UNISINOS, Escola Politécnica- itt Performance- Instituto tecnológico em desempenho e construção civil, Avenida Unisinos, 950, CEP 93022-750, São Leopoldo, RS, Brasil,

${ }^{2}$ UNISINOS, Escola Politécnica, Programa de Pós Graduação em Engenharia Civil- PPGEC, Avenida Unisinos, 950, CEP 93022-750, São Leopoldo, RS, Brasil,

${ }^{3}$ UNISINOS, Escola Politécnica, Programa de Pós Graduação em Engenharia Civil- PPGEC, - itt Performance- Instituto tecnológico em desempenho e construção civil, Avenida Unisinos, 950, CEP 93022-750, São Leopoldo, RS, Brasil

Email: fernandapache@unisinos.br, michaelbm@unisinos.br, marlovak@unisinos.br, felicianeb@unisinos.br,

btutikian@unisinos.br
\end{abstract}

\begin{abstract}
Ahead of the incorporation of residues in concrete composition, there is a decline in the environmental impact of buildings. One of the goals of today's development is the employment of low-impact energy sources, such as thermoelectric. Thermoelectric industries display a high rate of residues, among which is pointed out coal bottom ash (CBA) (15\% total residues), which have density superior to fly ash and accumulates in silos. Considering this scenario, this paper assessed the incorporation feasibility of CBA in the composition of cellular concrete, replacing silica fume. This study comprehended CBA characterization and application. For such, it was performed a scanning electron microscope (SEM) associated with Energy dispersive spectroscopy (EDS) analysis, laser granulometry, X-ray diffraction (XRD), X-ray efflorescence and density. Following the incorporation of the residues in cellular concrete in place of silica fume, it was performed compression strength analysis and SEM anew, evaluating the impact of CBA's insertion in concrete's microstructure. The $\mathrm{XRD}$ results are complementary to the other analyses. With SEM technique, it was observed the predominance of spherical-shape particles. The compressive strength of CBA concretes was superior to the reference concrete from 0,13 to $0,74 \mathrm{MPa}$.
\end{abstract}

Keywords: cellular concrete, coal bottom ash, characterization.

\section{RESUMO}

Diante da incorporação de resíduos no concreto, ocorre uma diminuição do impacto ambiental das edificações. Um dos objetivos do desenvolvimento atual é o emprego de fontes de energia de baixo impacto, como a termelétrica. As indústrias termelétricas apresentam um alto índice de resíduos, entre os quais se destacam as cinzas pesadas de carvão (coal bottom ash, CBA) (15\% resíduos totais), que possuem densidade superior às cinzas volantes e se acumulam nos silos. Diante desse cenário, o presente trabalho avaliou a viabilidade de incorporação da CBA na composição do concreto celular, em substituição à sílica ativa. Este estudo compreendeu a caracterização e aplicação da CBA. Para tal, foi realizada microscopia eletrônico de varredura (MEV) associado à análise de energia dispersiva (EDS), granulometria a laser, difração de raios X (DRX), eflorescência de raios X e densidade. Após a incorporação dos resíduos no concreto celular substituindo a sílica ativa, foi realizada análise de resistência à compressão e novamente $\mathrm{MEV}$, avaliando o impacto da inserção da CBA na microestrutura do concreto. Os resultados de XRD são complementares às outras análises. Com a técnica SEM, observou-se a predominância de partículas com formato esférico. A resistência à compressão dos concretos CBA foi superior ao concreto de referência variando de 0,13 a $0,74 \mathrm{MPa}$.

Palavras-chave: concreto celular, cinza pesada de carvão, caracterização 


\section{INTRODUCTION}

In light concrete development, it is aimed the decrease in density [1], increasing the acoustic and thermal performance [2], and also minimum mechanical resistance properties, allowing its application in walls. As an example of light concretes developed, it is possible to highlight the cellular concrete (CC). JITCHAIYAPHUM et al. [3] classify it as a type of concrete which air incorporation through the usage of chemical additives, with the possibility of pozzolanic insertion. CC can be obtained through the reaction of the agglomerates with specially added agents, such as metallic aluminum (Al), whose reaction with calcium hydroxide $(\mathrm{CaOH})$ releases hydrogen $(\mathrm{H})$ and forms voids in the cement paste [4].

Alongside the development of special concretes, it is studied the insertion of residues in concretes, whether as a partial or a total substitution of cement or natural aggregates $[2,5,6]$. The exploration of great volumes of natural resources, the high energetic intake and the emission of greenhouse effect gases deliver environmentally negative characteristics to the cement industry [7-10]. Therefore, replacing the cement is one of the trends in the development of the composites. With respect to natural aggregates, its use is predominantly verified in the construction area [11], needing to take into consideration the damages from sand extraction [12]. Coal bottom ashes (CBA) are residues originated from thermoelectrical plants and represent $15 \%$ of all the ash generated in this sort of industry. These ashes may replace the aggregates and the concrete binders as well, with no damage to the characteristics of the materials that compose it, [1, 13-14]. Thus, this article aims the development of cellular concretes, substituting their natural aggregates for CBA, verifying the characteristics of the achieved composite and limitations to its use.

$\mathrm{CC}$ is made of air or gas bubbles in a solid matrix, incorporated in it through chemical or mechanical processes. They are divided in two great groups, being the aerated with foamy agent and the chemically aerated, sustaining its difference in the shape of the pores and origin [15]. According to MA et al. [16], the material presents closed pores structure, granting excellent thermal and acoustic insulation, added to is its fire resistance and low thermal transmittance [17]. However, with low resistance due to its high porosity [18].

Regarding the use of residues in these materials, the incorporation of mineral additions is pointed out, such as pozzolans, replacing the conventional aggregates, once it allows a voids uniform distribution [3]. ROSTIROLA [19] assessed the incorporation of concrete fines originated from the construction recycling residues, verifying the possibility of creation of $\mathrm{CC}$ with these materials, once its incorporation provided an increase in the density and resistance to compression, making its usage feasible.

Thermoelectrical plants, which employ the charcoal burning are effective sources of energy, but they generate relevant amounts of residues, such as fly ash and the heavy ash [20]. Fly ash already has demand in the cement industry, however, bottom ash, which represents $15 \%$ of the total amount of residues generated, still doesn't have a marketplace for its recycling. According to the same authors, the chemical analysis of CBA may gather indicatives about its use in construction materials.

SINGH e SIDIQUE [14, 21] evaluated the insertion of CBA, originated from India's thermoelectrical plants, at different percentages in concrete, replacing natural sand (particles passing in 4,75mm sieve). They noticed that heavy ash has usage potential, once it modifies, in a small scale, the properties of the concretes generated, with no damage to its mechanical performance. Also, in the compositions containing CBA as fine aggregate, the chemical reactions occurs in a slower manner when compared to the reference concretes, postponing the gain of mechanical resistance of these materials.

On the other hand, Wongkeo and Chaipanich [22] chose its use in substitution of cement, regarding the composition of cellular concretes with structural purpose. The results obtained were satisfactory, among which is highlighted the increase of resistance to compression and a denser microstructure due to the residue use.

The utilization of ash in place of cement, as well as its use as fine aggregate, replacing natural sand, for instance, require researches that are able to characterize the aggregate and/or binder according to properties, such as: particle size analysis, chemical composition, microstructure, dimensions, among others. Blissett and Rowson [23] emphasize that being a residue originated from the burning of several organic and inorganic components, its composition varies, becoming a complex material to be characterized.

The specific applications of this material demand specific procedures of characterization. KADIR et al. [24] assessed the presence of heavy metals through toxicity experiments in samples containing coal bottom ash. KADIR et al. [25] performed SEM, concluding that the usage of heavy ash in replacement of natural sand introduced pores and incremented the rugosity of the set of aggregates, which led to an increase in friction among the particles. 
SINGH and SIDIQUE [14] evaluated the CBA in substitution of fine aggregate, verifying, through SEM, the expressive existence of voids that grants to the composite and elevated water absorption characteristic. In addition to this study, aiming to obtain information about the mineralogical and microstructural composition of the residue, the authors applied the XRD, identifying as the main composites mullite $\left(\mathrm{Al}_{6} \mathrm{Si}_{2} \mathrm{O}_{13}\right)$, iron oxide $\left(\mathrm{Fe}_{2} \mathrm{O}_{3}\right)$, quartz $\left(\mathrm{SiO}_{2}\right)$ and tridymite $\left(\mathrm{SiO}_{2}\right)$. SING e SIDIQUE [26] identified anorthite $\left(\mathrm{CaAl}_{2} \mathrm{Si}_{2} \mathrm{O}_{8}\right)$, mullite, tridymite and quartz.

\section{EXPERIMENT}

It was employed the Portland cement free from pozzolanic additions with equivalence of Cement type III, by ASTM C150 [27]. As reference aggregate it was employed silica fume, passing on 200 sieve. Aluminum fume was used in surface treatment, being an expanding agent for the CC production. The quicklime used in this study was the hydrated lime type, with a high rate of $\mathrm{CaO}$ [19]. The $\mathrm{CBA}$ is originated from the thermoelectrical plant located in Brazil, utilizing the passing fraction on the sieve whose mesh opening was $0,15 \mathrm{~mm}$.

The particle size distribution of the materials used was obtained through laser granulometry, with Microtrac equipment. The samples of heavy ash, aluminum fume, quicklime, and silica fume were prepared using dispersing agent of sodium hexametaphosphate. For these samples, it was employed as vehicle of analysis water. The cement was prepared with xylene, and the vehicle of analysis was isopropyl alcohol. The CBA residue used, as well as the other components, was assessed with respect to its density through the method of helium pycnometry, in accupic equipment II-1340.

\section{Characterization techniques of CBA and other components}

The qualitative materials chemical composition was identified via X-ray efflorescence technique, with spectrometer EDX 720HS. The SEM associated to EDS, was performed on the sample of CBA residue and on a sample of cellular concrete containing the residue, with an electronic microscopic scanning, from Zeiss brand. The sample was previously kept in the stove until mass constancy, in desiccator, and after, metallized using gold.

For the X-ray diffraction test, the material was prepared with the usage of an agate grail, so as all the sample would correspond to a fraction passing in the 325 Mesh sieve. The analysis was performed with an angle lapse from $5^{\circ}$ to $75^{\circ}$, time 1 second and pace 0,05 . The equipment used is Siemens, model D5000. For the interpretation of the diffractogram, it was used the software Expert High Score, from Phillips.

\section{Preparation of the concrete samples and characterization}

Concrete samples were based on the ratio presented in Table 1 [19]. It was investigated a total substitution of silica fume for CBA. It was employed a mass of fly ash equivalent to the volume of silica fume employed in the reference sample.

Table 1: Components of cellular concrete

\begin{tabular}{c|c|c|c|c}
\hline MATERIAL & CEMENT & QUICKLIME & CBA & ALUMINUM FUME \\
\hline Mass (g) & 100 & 12,5 & 137,5 & 4,38 \\
\hline
\end{tabular}

The water/dry materials ratio was 0,54 , for the molding, firstly, the dry materials were mixed, and water was added subsequently. Figure 1 shows the concrete volume that was filled halfway the forms and the expansion occurred through time. The samples were unmolded $24 \mathrm{~h}$ after their molding and, right after, were submitted to thermal curing in the stove for $72 \mathrm{~h}$ at $60^{\circ} \mathrm{C}$. After, the samples were kept in a controlled humidity and temperature room $\left(23+/-2^{\circ} \mathrm{C}\right.$ e $\left.65+/-5 \%\right)$ until the mechanical test. Also, the samples were set to a superficial regularization and coated with a layer of plaster in its superior and inferior faces. 


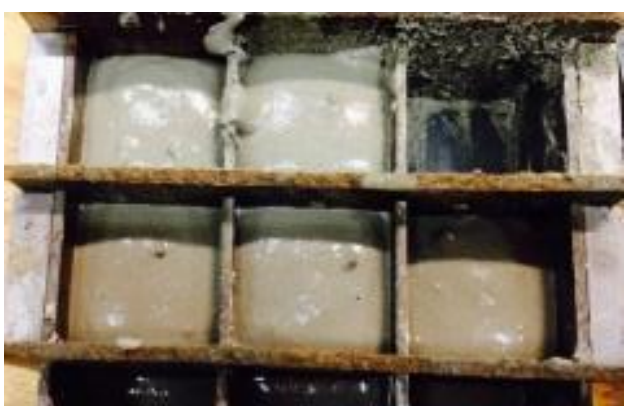

(a)

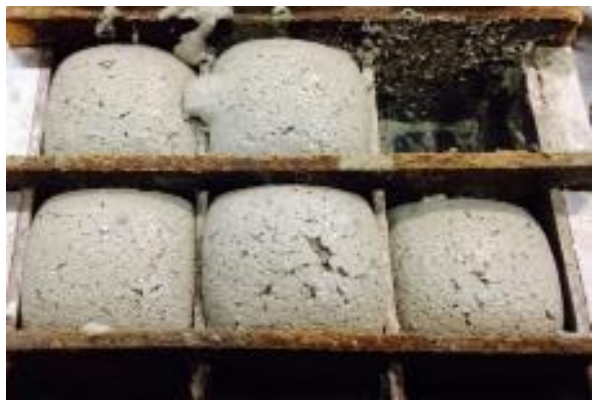

(b)

Figure 1: Specimens in fresh state, resting periods of (a) $2 \mathrm{~min}$ (b) $15 \mathrm{~min}$

After 12 days, it was performed the compression test, counting on the analysis of 3 cubic specimens, edge $40 \mathrm{~mm}$. the equipment used for this analysis was the EMIC's universal testing machine, with a loading speed of $0,05 \mathrm{MPa} / \mathrm{s}$. For the density verification, 3 specimens (edge of $40 \mathrm{~mm}$ ), were measured in relation to its mass and its volume.

\section{RESULTS}

\subsection{Materials characteristics}

Figure 2 and Table 2 presents the results from particle size distribution of CBA and the other components.

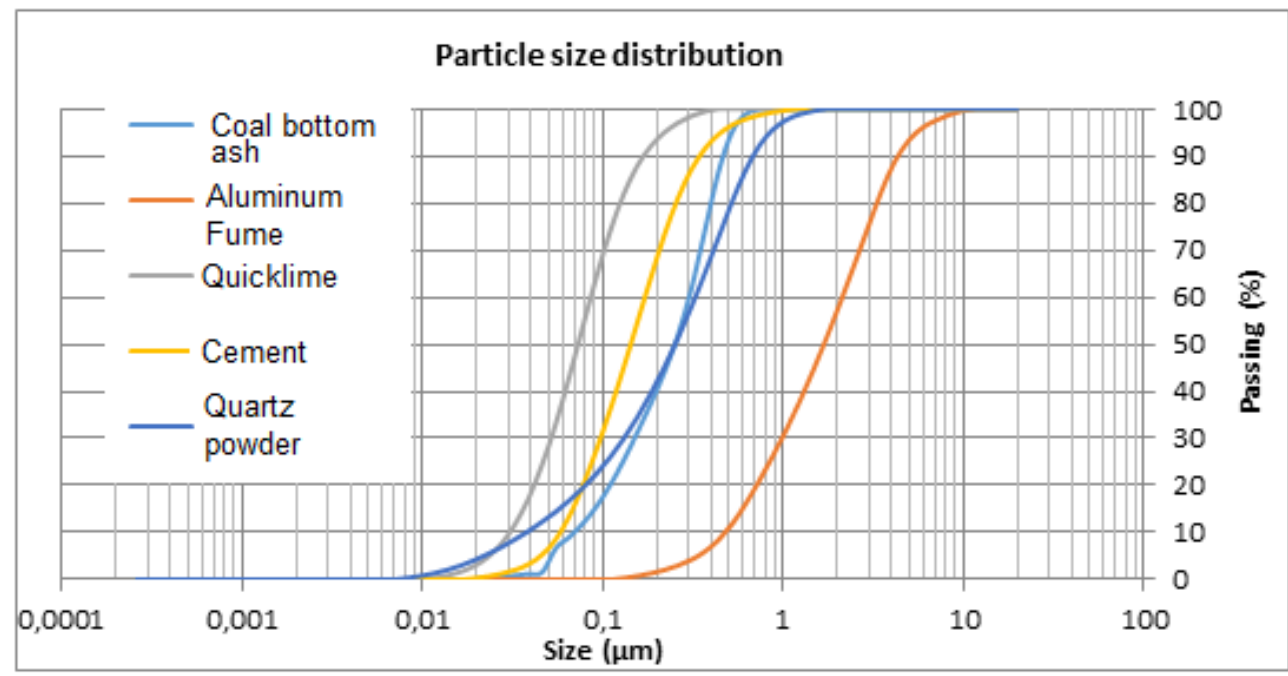

Figure 2: Materials particle size distribution

Table 2: Materials characteristic diameter $(\mu \mathrm{m})$

\begin{tabular}{c|c|c|c|c|c}
\hline MATERIAL & COAL BOTTOM ASH & SILICA FUME & ALUMINUM FUME & CEMENT & QUICKLIME \\
\hline $\mathrm{D} 10(\mu \mathrm{m})$ & 8,26 & 3,76 & 47,92 & 5,34 & 3,05 \\
\hline $\mathrm{D} 50(\mu \mathrm{m})$ & 29,95 & 25,27 & 169,4 & 15,21 & 7,30 \\
\hline $\mathrm{D} 90(\mu \mathrm{m})$ & 55,39 & 68,41 & 436,1 & 33,95 & 16,84 \\
\hline
\end{tabular}

It was observed a higher proximity of the ash with silica fume, followed by the cement curve. This equivalent distribution for the two materials confirms the information obtained in bibliography, extolling the usage possibility of the material as aggregate or binder $[20,21]$. The difference between fly ash particles and silica fume is more evident when assessing the characteristic diameters D10 and D90. With respect to the dimension of particles, SING; SIDDIQUE [21] affirm that in their ash of study $17,19 \%$ of the particles were 
passing in the sieve of opening $150 \mu \mathrm{m}$. LI et al. [28] used ashes whose D50 values were 22.05, 21.60 and 15.94 , in opposite to the value of 29,95 found.

However, the quicklime and aluminum fume curve displayed a distribution with a meaningful difference from the other materials. The particle size distribution of aluminum fumes may affect the reactivity with the calcium hydroxide and due to this lead to a lower formation of voids in the cellular concrete. Besides that, it is acknowledged that higher formation of voids occurs with smaller particles and, consequently, bigger superficial area [29].

The results of materials density are presented in Table 3, considering the average value among the three samples.

Table 3: Values obtained for density on the composites used in the concrete

\begin{tabular}{l|c}
\hline MATERIAL ASSESSED & DENSITY $\left(\mathbf{G} / \mathbf{C M}^{3}\right)$ \\
\hline Aluminum fume & 2,27 \\
\hline Portland Cement CP-V & 3,03 \\
\hline Quicklime & 2,28 \\
\hline Silica fume & 2,65 \\
\hline CBA & 2,10 \\
\hline
\end{tabular}

The CBA stands out, showing a smaller density, $2,10 \mathrm{~g} / \mathrm{cm}^{3}$. With respect to the reference material, silica fume, the residue is characterized by the value of density $21 \%$ inferior. This reduction may contribute for a decrease of density in cellular concrete, as long as it grants the occurrence of expansion and the volume obtained. The density varies according to the process of the thermoelectrical industry. SINDI and SIDDIQUE [14] verified the value of $1,39 \mathrm{~g} / \mathrm{cm}^{3}$, while Argiz et al. [29] obtained the value of 1,74, KIM and LEE [31] of $1,87 \mathrm{~g} / \mathrm{cm}^{3}$, PARK et al. [13] of $2,10 \mathrm{~g} / \mathrm{cm}^{3}$. Thus, the value obtained is within the range of values pointed in bibliography.

\subsection{Advanced analysis}

The results obtained in the X-ray fluorescence test are displayed in Table 4.

Table 4: Results obtained for aluminum fume, quicklime, silica fume and CHA's XRF.

\begin{tabular}{l|c|c|c}
\hline \multicolumn{1}{c|}{ SAMPLE } & $\begin{array}{c}\text { MAJOR ELEMENTS } \\
(\mathbf{5 0 \% )}\end{array}$ & $\begin{array}{c}\text { LESSER QUANTITY } \\
(\mathbf{5} \%<\mathbf{X}<\mathbf{5 0 \% )}\end{array}$ & TRACE ELEMENTS $\quad(<\mathbf{5 \% )}$ \\
\hline Aluminum fume & $\mathrm{Al}$ & - & $\mathrm{Si}, \mathrm{Ca}, \mathrm{Mg}, \mathrm{Mn}, \mathrm{Fe}, \mathrm{K}, \mathrm{Ti}, \mathrm{Cr}, \mathrm{W}, \mathrm{Zr}, \mathrm{Zn}$ \\
\hline Quicklime & $\mathrm{Ca}$ & - & $\mathrm{Sr}, \mathrm{Si}, \mathrm{Fe}, \mathrm{K}, \mathrm{S}, \mathrm{Tb}, \mathrm{Mn}$ \\
\hline Silica fume & $\mathrm{Si}$ & - & $\mathrm{Al}, \mathrm{Fe}, \mathrm{Pt}, \mathrm{Au}$ \\
\hline CBA & $\mathrm{Si}$ & $\mathrm{Al}, \mathrm{Fe}$ & $\mathrm{K}, \mathrm{Ca}, \mathrm{Ti}, \mathrm{Mg}, \mathrm{Zr}, \mathrm{Mn}, \mathrm{Sr}, \mathrm{S}, \mathrm{Rb}, \mathrm{Zn}, \mathrm{Cu}$ \\
\hline
\end{tabular}

Both the residue (CBA) and the replaced material (silica fume) present silicon ( $\mathrm{Si}$ ) as the main element. The aluminum fume sample, as expected, showed how quicklime possesses as main chemical composition element Ca. BLISSETT; ROWSON [23] obtained in the analysis of CBA the following components as main: silicon, aluminum, iron and calcium, leading to a similarity between the analyzed material and the study object. LATIFI et al. [32] affirm that heavy ash, in its composition, contains silicon, aluminum oxide, iron oxide and calcium oxide. With such chemical composition, it is noticed that there is a secondary reaction of the ash with cementitious components, providing a new gel formation of $\mathrm{C}-\mathrm{S}-\mathrm{H}$, and leading to a higher mixture density [32]. Figure 3 presents the composites identified with X-ray diffraction analysis. 


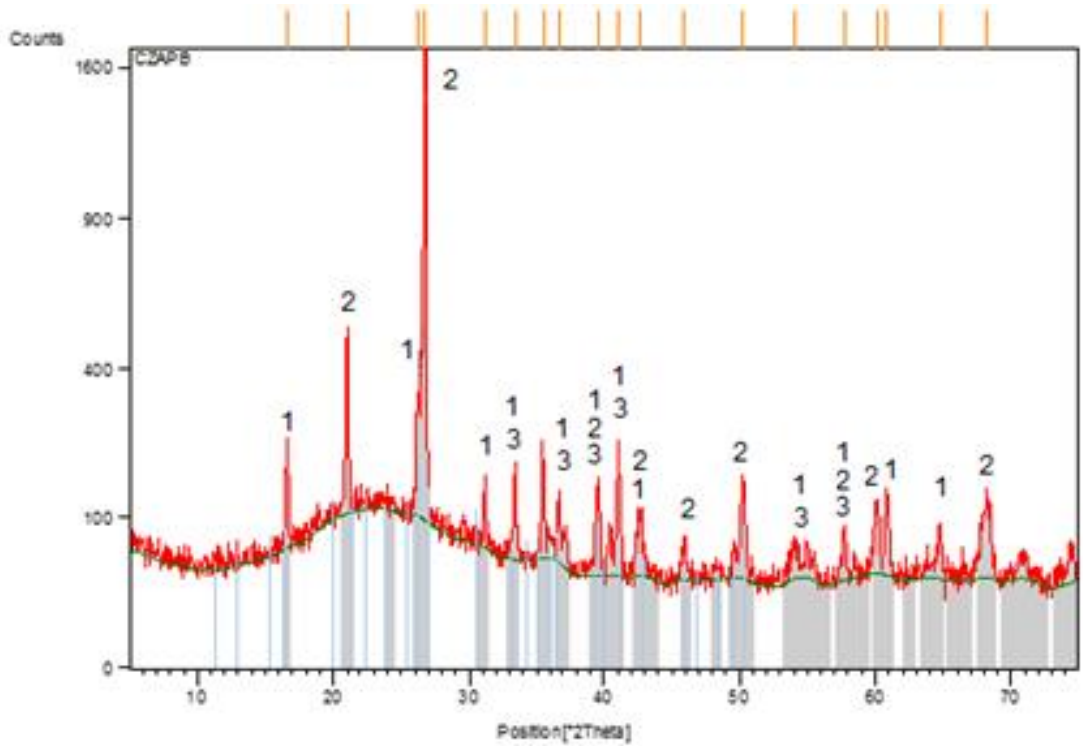

Figure 3: CBA X-ray diffraction test -Minerals (1) Mullite (2) Quartz (3) Hematite

As shown in Figure 3, there was presence of quartz $\left(\mathrm{SiO}_{2}\right)$, mullite $\left(\mathrm{Al}_{6} \mathrm{Si}_{2} \mathrm{O}_{13}\right)$ and hematite $\left(\mathrm{Fe}_{2} \mathrm{O}_{3}\right)$. The presence of these materials goes towards the identification made by SINGH e SIDIQUE [14]. Other studies also verified the same components, adding the presence of calcium oxide $(\mathrm{CaO})[13,31,33]$. The Mullite $\left(\mathrm{Al}_{6} \mathrm{Si}_{2} \mathrm{O}_{13}\right)$ found corresponds to the XRF analysis, considering that this test pointed out the elements that compose this material as it is presented in the sample, despite its lower percentage. Wongkeo; Chaipanich [22] obtained through the XRD technique, the samples of heavy ash presenting mainly quartz and mullite, heading towards HASHEMI'S et al. [34] study.

Observing this analysis and XRF technique, it is emphasized that the results are suitable, once the chemical elements pointed out $\mathrm{Al}, \mathrm{Ca}$ and $\mathrm{Si}$ as main elements, they are components of quartz and mullite minerals verified in the XRD test. Analyzing the technique with the SEM, it is noted once again that there is a relation among the chemical characterization of the materials, verifying the presence, in the analyzed spectra, of Al, Si, Ca and Ni. Studies [31,35] highlight that due to the amorphism, it seems like a pozzolanic reaction had occurred, leading to a formation of a gel and matrix thicken. Figure 4 shows the micrographies obtained from silica fume (a) and from the CBA (b).

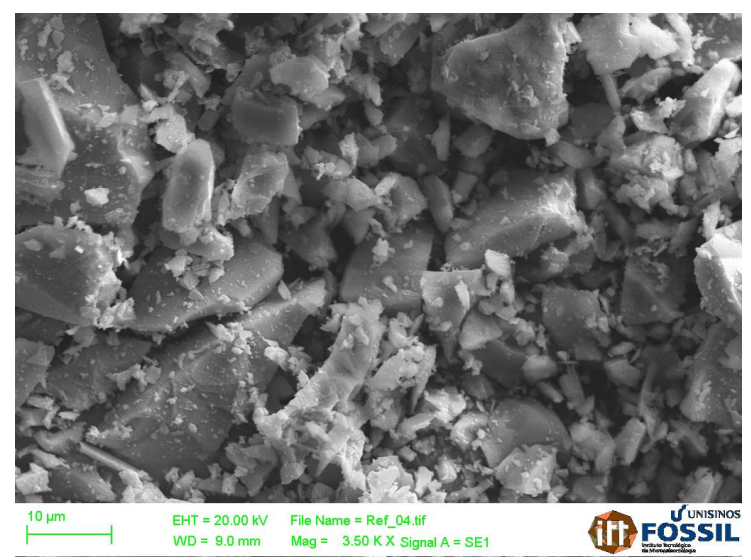

(a)

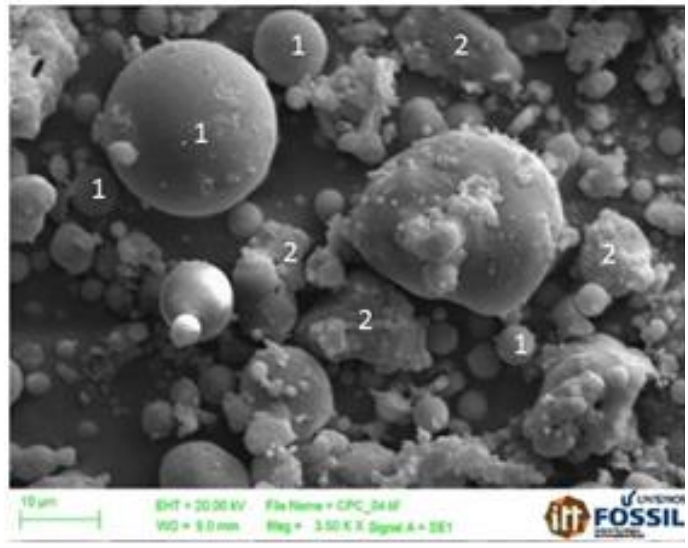

(b)

Figure 4: Micrographies (3500 times magnification): (a) silica fume; (b) CBA, with spherical-shaped particles (1) and irregular-shaped particles (2).

In Figure 4, it is possible to verify that the particles from both materials used as aggregates show similar particle sizes, confirming its particle size distribution. While silica fume is characterized essentially for its more defined edges, in CBA it is noted the presence of spherical particles, typical from ash generated from the charcoal burning, as well as irregular-shaped particles. In literature, it is found reports from both particles. 
WHILE TOPÇU et al. [36], among other researchers, observed the predominance of the spherical shape, LI et al. [28]; and others [13, 32, 33] noticed the predominance of irregular shape. Irregular-shaped particles observed in CBA are explained by HASHEMI $e t$ al. [34], which affirm that ash particles are more fragile, breaking apart easily generating its irregular shape. Differently, SINGH and SIDDIQUE [14, 21] characterized a great porosity in CBA. Therefore, while particle sphericity may help in consistency and rheology of $\mathrm{CC}$, an important characteristic for the obtainment of a homogeneous distribution of void formation, its porosity may increase the demand for water from the mixture in order to obtain adequate consistency.

With respect to the occurrence of pozzolanic reaction, through the SEM images its noticeable indications of reaction products on the surface of the particles of CBA.

On the EDS analysis on the ash's particles, it was obtained the presence of $28 \%$ aluminum (Al), $60,8 \%$ silicon $(\mathrm{Si}), 6,3 \%$ iron and inferior amounts at $2 \%$ of $\mathrm{K}, \mathrm{Ti}$, and $\mathrm{Ca}$, at descending order, all these percentages being mass-verified. Figure 5 displays micrographies from reference concretes with CBA (3500x magnification), as well as the identification of result points from the analysis of EDS. Analyses were performed in a region of the reference concrete and in three regions on the sample containing CHA, being the results displayed on Table 5 .

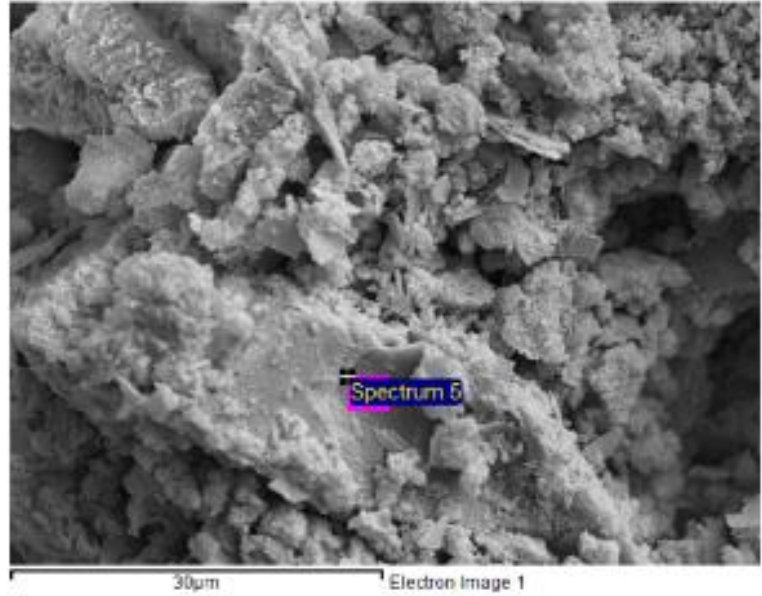

(a)

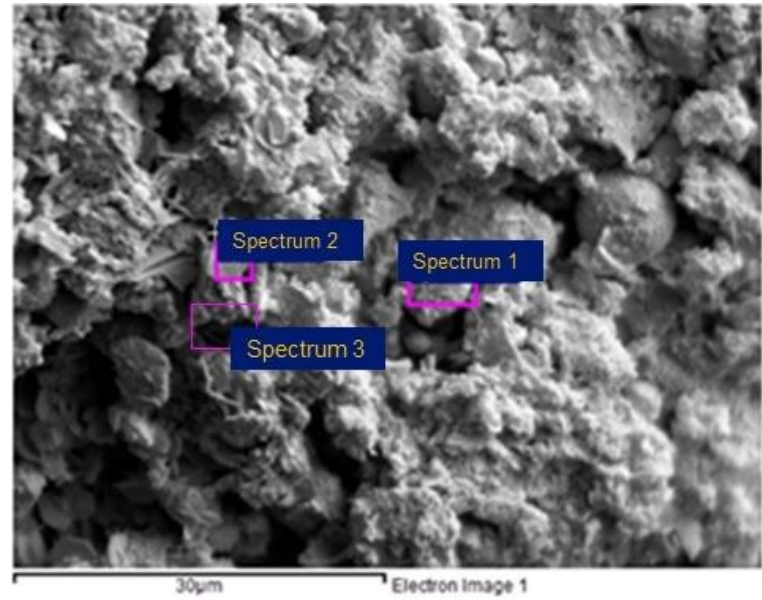

(b)

Figure 5: Concrete micrographies and EDS sis: (a) reference, analysis spectrum 5; and (b) with CBA, spectrum analysis 1,2 and 3 .

KIM and LEE [35] perceived through the SEM technique a higher density in the transition zone when comparing the concrete containing heavy ash to a concrete with conventional composition. The authors points out that: matrix.

a) The use of CBA provides a rougher surface and grants greater anchorage with the cementitious

b) Water may deposit on aggregates to improve cement's hydration ratio, and therefore, having denser hydration products system at the interface with the aggregates;

c) The surface of light aggregates may react to cement due to their pozzolanic properties.

On the study in analysis, higher densification seems to occur not only at the transition zone but also on other regions of samples with CHA, when compared to silica fume. It is observed that the presence of spherical-shaped particles from the residue still remain present on the concrete produced with CBA.

Besides that, as WONGKEO and HAIPANICH [22], on the images analyses, it was verified the presence of formations with morphologies similar to fish scale. Some literatures compare these formations to the development of analogue composites to this tobermorite, whose chemical composition shows C-S-H [19]. In fact, these scales may be associated with C-S-H formation in higher temperatures and crystalized in it microstructure with a major presence of voids. Regarding $\mathrm{CC}$, the presence of voids is related to the release of $\mathrm{H}$ gas when $\mathrm{Al}$ reacts with calcium hydroxide. 
Table 5: Data referring to the identified elements - EDS spectra 1, 2 and 3, analysis on concrete samples with CBA and grains of CBA.

\begin{tabular}{c|c|c|c|c|c|c|c|c|c|c|c}
\hline \multicolumn{5}{c|}{ ANALYSIS OF CBA CONCRETE } & \multicolumn{5}{c}{ ANALYSIS PERFORMED ON CBA } \\
\hline \multicolumn{2}{c|}{ Spectrum 01 } & \multicolumn{2}{c|}{ Spectrum 02} & \multicolumn{2}{c|}{ Spectrum 03} & \multicolumn{2}{c}{ Spectrum 01 } & \multicolumn{2}{|c|}{ Spectrum 02 } & \multicolumn{2}{c}{ Spectrum 03 } \\
\hline $\mathrm{E}$ & $\mathrm{C}$ & $\mathrm{E}$ & $\mathrm{C}$ & $\mathrm{E}$ & $\mathrm{C}$ & $\mathrm{E}$ & $\mathrm{C}$ & $\mathrm{E}$ & $\mathrm{C}$ & $\mathrm{E}$ & $\mathrm{C}$ \\
\hline \multirow{2}{*}{$\mathrm{Al}$} & 3,34 & $\mathrm{Al}$ & 5,35 & $\mathrm{Mg}, \mathrm{K}$ & $\begin{array}{c}\text { Less than } \\
2 \%\end{array}$ & $\mathrm{Al}$ & 26,22 & $\mathrm{~N}$ & 64,5 & $\mathrm{Al}$ & 14,16 \\
\hline $\mathrm{Si}$ & 25,65 & $\mathrm{Si}$ & 35,77 & $\mathrm{Al}$ & 18,33 & $\mathrm{Si}$ & 52,86 & $\mathrm{Al}$ & 8,55 & $\mathrm{Ca}$ & 85,84 \\
\hline $\mathrm{Ca}$ & 70,99 & $\mathrm{Ca}$ & 58,87 & $\mathrm{Si}$ & 14,24 & $\mathrm{Ca}$ & 20,92 & $\mathrm{Ca}$ & 26,95 & & \\
\hline & & & & $\mathrm{Ca}$ & 53,46 & & & & & & \\
\hline
\end{tabular}

E: element; C: content

It is pertinent to highlight that the carbon element respects to a light material, and them, there may have flaws in its identification utilizing this technique [29], being this analysis only indicative.

The micro-region of analysis 1 was placed over a characteristic sphere of the residue, and that's why its similarity with the ash's DES in an isolate manner and its presence of silicon not identified at the others spectra. On the remaining spectra it was verified major presence of calcium and nitrogen, with little participation of aluminum. Punctual analysis 3 was performed in a laminar-like region, pointing to the perception of calcium, which may be an indicative of presence of $\mathrm{Ca}(\mathrm{OH})$.

Through the use of SEM+EDS, SINGH and SIDDIQUE'S [14] study pointed for 94,12\% of the sample being composed by silicon dioxide, aluminum oxide and iron oxide. TOPÇU; TOPRAK; GLU [34] verified that these composites were responsible for $78,84 \%$ of the ash analyzed in their study.

The results from compressive strength are shown in Table 6 for CC with CBA and reference CC.

Table 6: Compressive strength on CC containing CBA and reference CC

\begin{tabular}{l|c|c|c|c}
\hline SAMPLE & EDGE (MM) & LENGHT (MM) & LOAD (N) & TENSION (MPa) \\
\hline 01 & 39,15 & 39,01 & 1126 & 0,74 \\
\hline 02 & 39,77 & 40,32 & 1042 & 0,65 \\
\hline 03 & 39,58 & 39,86 & 781 & 0,50 \\
\hline Reference CC & 40 & 40 & 209 & 0,13 \\
\hline
\end{tabular}

Samples containing CBA showed higher values of compression strength. Still, it is remarkable that the developed material in this study did not count on the use of autoclave, which is a regular procedure on cellular concretes, benefiting the mechanical properties. LI et al. [27] perceived a decrease in mechanical resistance of CC when sand was replaced. The authors highlight that smaller fineness values in the ash displayed benefits in resistance to compression, being the maximum substitution percentage of the aggregate $60 \%$.

SINGH; SIDDIQUE [14] affirmed that at 28 days it was perceived a higher aproximation of the values of the mixture containing heavy ash replacing the aggregates. Sing;Siddique [20] pointed out 90 days as the age where concrete containing ash overcame resistance to compression values of conventional concretes. WONGKEO; CHAIPANICH [21], who also researched about CC, pointed out a benefit in compressive strength, once the samples containing $20 \%$ ash replacing the sand were the samples with greater values on this quantity. Table 7 presents the density values for both concretes

Table 7: Density results on concretes containing CBA and in the reference CC

\begin{tabular}{c|c}
\hline SAMPLE & DENSITY(KG/M $\left.\mathbf{M}^{3}\right)$ \\
\hline 01 & 754 \\
\hline 02 & 669 \\
\hline 03 & 676 \\
\hline Reference CC & 527 \\
\hline
\end{tabular}


The reference $\mathrm{CC}$ showed inferior value when compared to the samples utilizing CBA. Through density analysis, CBA was the one with smaller density, however it ended up being the concrete with higher mass. This may be an indication that the bottom ash may have created a barrier to expansion of the cellular concrete. The higher density may be attributed to a higher granulometry of aluminum fume, which reduces its pore formation and consequently leads to higher density values [37].

Picking up on what was affirmed by LATTIFI et al. [30] the higher density may be attributed to the formation of a secondary C-S-H gel, according to the chemical composition of CBA. Through EMS of the new CBA concrete it was perceived a higher matrix densification, elevating the relevancy of the higher density verified on the concretes.

\section{CONCLUSION}

The particle size test pointed for a similarity between CBA and the silica fume. The density of the developed concrete was superior to the reference, contradicting the smaller density of the residue regarding silica fume As mentioned, the high density may occurs due to barrier to expansion of the CC, justified by lower expansion occurred with the use of CBA. It is possible to sum up the verifications of bigger dimension of the particles and consequently the smaller formation of voids. Besides that, such results corroborate the fact of being verified a bigger densification at the EMS test.

At the SEM test, it was possible to verify the spherical shape of the particles, commonly cited in bibliography, its granulometric distribution (through particles visualization of different sizes) and the presentation of irregular surface at the concrete;

EDS test pointed the major elements in the residue, and when performed in the concrete, it found the same elements in approximation to the sphere in gray (micro region 1);

The X-ray fluorescence test pointed similarity between the utilized residue and the reference material, both with the predominance of silicon in its composition. Still, it was verified the aluminum purity;

At the X-ray diffraction test it was pointed the predominance of quartz, mullite and hematite. The presence of these materials is suitable with the identification of silicon as major chemical element (XRF) and at the residue's DES.

The compressive strength were superior at the samples containing CBA, majoring in $5 \mathrm{x}$ the value obtained by the reference. It is believed that the material may proceed its development analyzing different percentages of use of aluminum fume, applying the autoclave and performing the resistance to compression test in advanced ages, verifying if there are gains in resistance due to the use of pozolanes. Regarding reference concrete's density, it was perceived higher density on concretes using CBA, with an average value $33 \%$ superior to the reference concrete.

\section{AKNOWLEDGMENTS}

We thank itt Performance for the study carried out

\section{REFERENCES}

[1] SCHOON, J., et al. "Feasability study on the use of cellular concrete as alternative raw material for Portland clinker production". doi: 10.1016/j.conbuildmat.2013.07.083. Construction and Building Materials, v.48, pp.725-733, 2013.

[2] ALIABDO, A.A., ABD-WLMOATY A.M., HASSAN, H.H. "Utilization of crushed clay brick in cellular concrete production”. doi: 10.1016/j.aej.2013.11.005. Alexandria Engineering Journal, v.53, pp.119-130, 2014.

[3] JITCHAIYAPHUM, K., SINSIRIAM, T., CHINDAPRASIRTB, P. "Cellular Lightweight Concrete Containing Pozzolan Materials” doi:10.1016/j.proeng.2011.07.145. In: Proceedings of The Twelfth East AsiaPacific Conference on Structural Engineering and Construction. v.14, pp:1157-1164, 2011.

[4] RAMACHANDRAN, V.S. Concrete Admixtures Handbook. New Jersey: Noyes Publications, 2 edition, 1180p. 1996.

[5] KAWAI, K., OSAKO, M. "Reduction of natural resource consumption in cement production in Japan by waste utilization”. doi:10.1007/s10163-012-0042-4. Journal Mat Cycles Waste management, v.14, pp.94101, 2012.

[6] SUHENDRO, B. "Toward green concrete for better sustainable environment". doi: 10.1016/j.proeng.2014.12.190. In: 2nd International Conference on Sustainable Civil Engineering Structures and Construction - Procedia Engineering v.95, pp. 305-320, 2014. 
[7] YURDAKUL, E. (2010) Optimizing concrete mixtures with minimum cement content for performance and sustainability. Thesis- Civil Engineering, Iowa State University.

[8] GIRSKAS, G., et al. "Durability of concrete containing synthetic zeolite from aluminum fluoride production waste as supplementary cementitious material". doi: 10.1016/j.conbuildmat.2016.04.155. Construction and building materiais, v.117, pp.99-106, 2016.

[9] ROSTAMI, M., BEHFARNIA, K. "The effect of sílica fume on durability of alkali activated slag concrete". doi: 10.1016/j.conbuildmat.2016.12.072. Construction and building materials, v.134, pp.262-268, 2017.

[10] SALAS, D.A., et al. "Environmental impacts, life cycle assessment and potential improvement measures for cement production: A literature review". doi: 10.1016/j.jclepro.2015.11.078. Journal of Cleaner Production, v. 113, pp. 114-122, 2016.

[11] SARDINHA, M., BRITO, J., RODRIGUES, R. "Durability properties of structural concrete containing very fine aggregates of marble sludge". doi: 10.1016/j.conbuildmat.2016.05.071. Construction and building materials, v.119, pp. 45-52, 2016.

[12] GRABASCK, J.R. (2016). Aspectos e impactos ambientais decorrentes da extração de agregado natural e produção de agregado reciclado: estudo de caso no RS. Dissertation, Unisinos University.

[13] PARK, S.B., et al. "An experimental study on the hazard assessment and mechanical properties of porous concrete utilizing coal bottom ash coarse aggregate in Korea”. doi: 10.1016/j.jhazmat.2008.11.054. J Hazard Mater, v.166, pp. 348-55, 2009.

[14] SINGH, M., SIDDIQUE, R. "Properties of concrete containing high volumes of coal bottom ash as fine aggregate”. doi:10.1016/j.jclepro.2014.12.026. Journal of cleaner production, v.91, pp. 269-278, 2015.

[15] MELO. G.F (2009).Concreto Celular Polimérico: Influência da adição deresíduo de poliéster insaturado termofixo. Thesis- Universidade Federal do Rio Grande do Norte.

[16] MA, et al, "Utilization of iron tailings as substituite in cellular concrete: physico- mechanical and microstructure of hydration products”. doi: 10.1016/j.jclepro.2016.03.172. Journal of cleaner production, v.127, pp.162-171.

[17] KASHANI, A., et al. "A sustainable application of recycled tyre crumbs as insulator in lightweight cellular concrete". doi: 10.1016/j.jclepro.2017.02.154. Journal of cleaner production, v.149, pp. 925-935, 2017.

[18] DENG, Z., ZHONGGANG, H.C., ZHU, G., et al., "Compressive behavior of the cellular concrete utilizing millimeter-size spherical saturated SAP under high strain-rate loading". doi: 10.1016/j.conbuildmat.2016.05.018. Construction and building materials, v.199, pp. 96-106, 2016,

[19] ROSTIROLA, A.C.F (2013). Estudo exploratório da produção de concreto celular autoclavado com o emprego de finos oriundos da reciclagem de concreto como agregados. Dissertation, UNISINOS University Dissertação apresentada ao PPGEC, UNISINOS.

[20] KWON, W.T., KIM, D.H., KIM, Y.P. "Characterization of heavy oil fly ash generated from a power plant”. doi: 10.2240/azojomo0135. Advances in Technology of materials and materials processing, v.6, pp. 260-263, 2004,

[21] SINGH, M., SIDDIQUE, R. "Strength properties and micro-structural properties of concrete containing coal bottom ash as partial replacement of fine aggregate". doi: 10.1016/j.conbuildmat.2013.09.026. Construction and building materials, v.50, pp. 246-256, 2014,

[22] WONGKEO, W., CHAIPANICH, A. "Compressive strength, microstructure and thermal analysis of autoclaved and air cured structural lightweight concrete made with coal bottom ash and silica fume". doi: 10.1016/j.msea.2010.01.089. Cement and Concrete Research v.A527, pp. 3676-3684, 2010,

[23] BLISSET, R.S., ROWSON (2012). "A review of the multi-component utilisation of coal fly ash". doi: 10.1016/j.fuel.2012.03.024. Fuel v.97, pp.1-23,

[24] KADIR, A.A., HASSAN, M.I.H., ABDULLAH, M.M.A. "Investigation on leaching behaviour of fly ash and bottom ash replacement in self-compacting concrete". doi:10.1088/1757-899X/133/1/012036. In: International conference on Innovative Research. ICIR Euroinvent, v1, pp: 1-12, 2016.

[25] KADIR, A.A., et al. "Properties and leachability of self-compacting concrete incorporated with fly ash and bottom ash". doi: 10.1088/1757-899X/133/1/012039. In: International Conferente on Innovative Research. ICIR Euroinvent, 2016.

[26] SINGH, M., SIDDIQUE, R. "Compressive strength, drying shrinkage and chemical resistance of concrete incorporating coal bottom ash as partial or total replacement of sand". doi: 10.1016/j.conbuildmat.2014.06.034. Construction and building materials v. 68, pp. 39-48, 2014 b.

[27] ASTM C150-18 Standard Specification for Portland Cement.

[28] LI, et al. "Utilization of municipal solid waste incineration bottom ash in cellular concrete". Construction and building materials, doi: 10.1016/j.conbuildmat.2018.05.147. v. 178, pp.175-182, 2018.

[29] LEDNEV, et al. "Elemental profiling os laser cladded multilayer coatings by laser induced breakdown spectroscopy and energy dispersive X-ray spectroscopy”. doi:10.1016/j.apsusc.2017.04.108. Applied surface science. v.416, pp:302-307, 2017. 
[30] ARGIZ, C., MORAGUES, A., MENÉNDEZ, E.. Use of ground coal bottom ash as cement constituent in concretes exposed to chloride environments. Journal of Cleaner Production, doi:10.1016/j.jclepro.2017.09.117. v. 170, pp. 25-33, 2018.

[31] KIM, H.K., LEE, H.K. "Use of power plant bottom ash as fine and coarse aggregates in high-strength concrete". doi: 10.1016/j.conbuildmat.2010.06.065.Construction and building materials, v.25, pp.1115-1122, 2011

[32] LATIFI, et al, "Strength and physico-chemical characteristics of fly ash-bottom ash mixture." doi: 10.1007/s13369-015-1647-4. Arab Journal of Science Engineering v. 40, pp. 2447-2455, 2015.

[33] TORKITTIKUL, P., et al, "Utilization of coal bottom ash to improve termal insulation of construction material”. doi:10.1007/s10163-015-0419-2. J Mater Cycles Waste Manag, v. 19,pp. 305-317, 2017.

[34] HASHEMI, et al, "Microstrucutral characterization and mechanical properties of bottom ash mortar". doi: 10.1016/j.jclepro.2017.09.191. Journal of cleaner production, v.170, pp.797-804, 2018.

[35] KIM, H.K., LEE, H.K. "Hydration kinetics of high-strength concrete with untreated coal bottom ash for internal curing." doi:10.1016/j.cemconcomp.2018.04.017. Cement and concrete composites, v. 91, pp. 67-75, 2018 ,

[36] TOPÇU, I.B., TOPRAK, M.U., UYGUNOGLU, T. "Durability and microstructure characteristics of álcali activated coal bottom ash geopolymer cement". doi: 10.1016/j.jclepro.2014.06.037. Journal of cleaner production, v.81, pp. 211-217, 2014.

[37] SHABBAR, R.S.. NEDWELL, P., WU, Z. "Effect of aluminium poder grading on the properties of cellular concrete". In: 36th Cement and Concrete Science Conference. Cardiff, September, 2016.

\section{ORCID}

Fernanda Pacheco

Michael Anderson Bica Moreira

Marlova Piva Kuwakowiski

Feliciane Andrade Brehm

Bernardo Fonseca Tutikian
http://orcid.org/0000-0003-3455-491X

https://orcid.org/0000-0002-7563-656X

https://orcid.org/0000-0002-7661-3909

https://orcid.org/0000-0002-3272-5837

https://orcid.org/ 0000-0003-1319-0547 